\title{
DAVALAC IZDRŽAVANJA KOD UGOVORA O DOŽIVOTNOM IZDRŽAVANJU
}

\section{UvoD}

Ugovor o doživotnom izdržavanju, kao jedan vrlo kompleksan pravni posao, izaziva u teoriji i praksi brojne sporove. Ti sporovi se, između ostalog, javljaju i u vezi sa pitanjem sposobnosti samih ugovarača za zaključenje ovog ugovora. Ovo pre svega zbog nepotpune zakonske regulative i mešavine porodičnih, naslednih i obligacionih odnosa koji se javljaju kod zaključenja i dejstava ovog ugovora. Sve to je ostavilo dosta širok prostor za razna tumačenja i nejasnoće, pre svega u pogledu sposobnosti određenih lica da budu davaoci izdržavanja.

Iako o ugovoru o doživotnom izdržavanju u nauci postoji nekoliko kapitalnih dela, čini mi se da je u svima njima pitanje ko sve može biti davalac izdržavanja na neki način zapostavljeno ili, preciznije, smatram da nije u dovoljnoj meri razjašnjeno, što je uz neizbežno postojanje različitih i često suprotstavljenih stavova među autorima dovelo do šarolikosti konkretnih rešenja, što je bez sumnje uticalo i na praksu. Stoga u ovom radu želim pre svega da analizom zakonskih tekstova, sudskih odluka i teorijskih stavova rasvetlim ovo pitanje, bar kada je reč o pozitivnom pravu Republike Srbije, i na taj način učinim ovo pitanje manje komplikovanim, samim tim i jednostavnijim za primenu.

Prilikom ispitivanja nastanka ugovora o doživotnom izdržavanju, kao i koja su se lica javljala kao davaoci izdržavanja na samim počecima pravnog života ovog ugovora, koristiću, neizbežno, istorijski metod. Takođe, budući da je ovaj ugovor nastao u određenim društvenim uslovima, ali i da svoju sadašnju egzistenciju takođe duguje određenoj društvenoj svrsi, sociološki metod se nameće kao neophodan u ovom radu. Komparativni metod ću koristiti u onoj meri u kojoj je to neophodno da bih ukazao na jednu širu sliku nastanka i regulisanja ovog ugovora u uporednom pravu, kao i da bih ukazao na pojedina rešenja o kojima vredi razmisliti kao odgovarajućim i za naše pravo. Primena normativno-dogmatičkog metoda je neophodna prilikom proučavanja i analize zakonskih rešenja, kako važećih tako i nekih ranijih, sada nevažećih. Konačno, u radu će biti korišćen metod analize pojedinih slučajeva u kojima

* $\quad$ Student Pravnog fakulteta Univerziteta Union u Beogradu 
se kao sporno javlja sposobnost određenog lica da bude davalac izdržavanja kod ugovora o doživotnom izdržavanju.

U prvom delu rada, posvetiću se nastanku ovog ugovora u pravnoj praksi, sa posebnim osvrtom na to ko se sve u tom periodu javlja u ulozi davaoca izdržavanja, kako kod nas tako i uporedno pravno. Zatim ću ukazati na to kada se ovaj ugovor prvi put reguliše u zakonskim propisima i kako je njegov život u pravnim propisima tekao do sada, kao i kakva je njegova istorija u zakonodavstvu na našim prostorima. U drugom delu rada, pokušaću da obradim neka od spornih pitanja koja su se javila u praksi sudova ali koja u manjoj ili većoj meri i dalje egzistiraju kao sporna u pravnoj teoriji. Pri tome ću nastojati da što je više moguće iznesem sve ključne argumente suprotstavljenih stavova ili mišljenja po pojedinim od ovih pitanja. Sve ovo ću pokušati da dočaram i bogatom praksom naših sudova u ovoj materiji i uz to, nadam se, da pokažem u kojem je pravcu ona evoluirala.

U zaključku ću pokušati da iznesem pojednostavljenu sliku o tome ko sve može biti davalac izdržavanja kod ugovora o doživotnom izdržavanju i pod kojim uslovima. Takođe, ukazaću i na postojeća ograničenja koja se javljaju in concreto i čine određeno lice nesposobnim da zaključi ugovor o doživotnom izdržavanju u svojstvu subjekta davaoca izdržavanja, iako to isto lice uzeto in abstracto ispunjava sve uslove da bude davalac izdržavanja.

\section{ISTORIJSKI PRIKAZ}

Kad i zašto se javlja ugovor o doživotnom izdržavanju? Ugovor o doživotnom izdržavanju prvi put se javlja u ranom srednjem veku. Potreba za doživotnim izdržavanjem javlja se pre svega kod ostarelih i iznemoglih kmetova koji su putem ovog pravnog instituta obezbeđivali sebi mirnu starost jer su imanje ustupali mlađim i za rad sposobnijim licima koja su ih za uzvrat „izdržavala“ do kraja života. Na pojavu ovog ugovora u pravnom životu baš $\mathrm{u}$ tom periodu uticalo je više razloga proisteklih iz tadašnjih društveno-ekonomskih uslova života. Nastao u sistemu feudalnih društvenih odnosa, ovaj ugovor je poslužio kao pogodan institut ostarelim kmetovima, koji više nisu bili u mogućnosti da feudalnom gospodaru plaćaju raznorazne namete, da sebi obezbede mirnu starost tako što će na neko mlađe i za rad sposobnije lice preneti imanje ali i obavezu davanja raznih nameta feudalnom gospodaru. Ovaj ugovor je zbog toga odgovarao i interesima feudalnih gospodara jer je na taj način obezbeđivana veća korist nego što bi bila samo od imanja ostarelog kmeta. O interesu feudalnih gospodara za zaključivanje ovih ugovora svedoči i to da je u „nekim pokrajinama u Nemačkoj bilo predviđeno da je za ustupanje imanja u naknadu za doživotno izdržavanje potrebna saglasnost feudalnog gospodara". ${ }^{1}$ Feudalni sistem, u kojem je ostarelog kmeta posle smrti

1 Dr Nevenka Subotić-Konstantinović, Ugovor o doživotnom izdržavanju, Beograd 1968, str. 20. 
nasleđivao njegov feudalni gospodar a ne porodica, uticao je i na to da se ovim ugovorom obezbeđivalo da i posle smrti kmeta njegov posed ostane u posedu njegove porodice, pre svega njegove dece ili bliskih srodnika. Dakle, u tom periodu ovaj ugovor se najčešće zaključivao između roditelja i dece (po pravilu najstarijeg sina kao davaoca izdržavanja) ili ukoliko ostareli kmet nije imao dece, kao davalac izdržavanja javljao se neko od bližih srodnika. Neretki su bili i slučajevi gde se kao davalac izdržavanja pojavljuju sva kmetova deca koja se obavezuju da se brinu i staraju o svojim roditeljima. Međutim, nisu bili nepoznati ni slučajevi u kojima se kao davalac izdržavanja javljalo neko lice izvan kruga srodnika. Tim licima je ovaj ugovor, pored egzistencije koju su dobijali, omogućavao i da zasnuju svoju porodicu i time izbegnu vojnu obavezu, na koju su inače bili obavezni prema svom feudalnom gospodaru.

Vrlo rano se kao davalac izdržavanja kod ugovora o doživotnom izdržavanju javljaju i pravna lica. Pre svega manastiri (posebno u Italiji, Švajcarskoj i Nemačkoj) i razne građanske ustanove kao što su u Švajcarskoj bili gradski zavodi i bolnice za doživotni smeštaj ili izdržavanje.

Ugovor o doživotnom izdržavanju u našim krajevima u srednjem veku. Doživotno izdržavanje se i na našim prostorima javlja dosta rano (već u XIV veku). Zasnivalo se ili ugovorom ili testamentom, a kao davalac izdržavanja pojavljuju se pre svega manastiri. Postojala je „praksa da svetovna lica darivaju manastire svojim dobrima, a za uzvrat dobijaju pravo na doživotno izdržavanje “2 $\mathrm{Na}$ taj način je manastir bio u obavezi da doživotno izdržava i neguje primaoca izdržavanja koji je sticao pravo na bratstvene delove, tzv. adelfate, adrfate ili komate. Prva do sada otkrivena kupovina ovih bratstvenih delova potiče s početka XIV veka. O njoj saznajemo iz jedne povelje kralja Milutina kojom on kupuje od manastira Hilandar tri komata za svoje kaluđere koji nisu pripadali manastirskom bratstvu. Pored ovog primera, sačuvani su i dokumenti o brojnim drugim ugovaranjima doživotnog izdržavanja tadašnje srpske vlastele sa manastirima (prvenstveno svetogorskim) kao davaocima izdržavanja. ${ }^{3}$ Pored ovih slučajeva, tokom čitavog srednjeg veka na našim prostorima ugovarano je ili na drugi način određivano doživotno izdržavanje i između srodnika, koje u poređenju sa istom praksom drugih evropskih zemalja nema nikakve specifičnosti u pogledu ličnosti davaoca izdržavanja, te se najčešće kao davaoci izdržavanja javljaju deca ili bliski srodnici primaoca izdržavanja.

Ugovor o doživotnom izdržavanju u srpskom pravu. Ugovor o doživotnom izdržavanju prvi put je u našem pravu regulisan saveznim Zakonom o nasle-

2 Oliver Antić, Nasledno pravo, Beograd 2010, str. 346.

3 O ovome više u: Dr Radoslav M. Grujić, Svetogorski azil za srpske vladaoce i vlastelu, Glasnik Skopskog učenog društva, knjiga 11, 1932, str. 71-81, kao i u: Dr Nevenka Subotić-Konstantinović, op. cit., str. 8-17. 
đivanju iz 1955. godine. ${ }^{4}$ Srpski građanski zakonik, po ugledu na svoje evropske uzore, takođe nije regulisao ovaj ugovor iako je on bio poznat u pravnoj praksi na ovim prostorima, gde je bio popularan naročito među seljačkim življem pod raznim imenima: „ugovor o zajednici života, rada i imanja“, „ugovor o nasleđivanju“, „ugovor o predaji“... Karakteristika ovog perioda (u kojem nije bilo zakonske regulative) jeste to da, za razliku od većine drugih evropskih zemalja, kod nas ugovore o doživotnom izdržavanju zaključuju najčešće strana lica, to jest lica koja nisu srodnici. Tako se najčešće kao primalac izdržavanja javlja jedno staro i samohrano lice (ili bračni par) koje nema dece ili čija deca nisu u stanju da ga izdržavaju, a kao davalac izdržavanja se javlja po pravilu mlađe za rad sposobno lice (ili bračni par) koje nije srodnik sa primaocem izdržavanja. Ova razlika u odnosu na praksu drugih evropskih zemalja iz tog perioda (u kojima su ovi ugovori najčešće zaključivani između roditelja i dece) objašnjava se relativno dugim postojanjem porodičnih zadruga u pojedinim krajevima naše zemlje. ${ }^{5}$

Posebno treba skrenuti pažnju da u ovom periodu, na području na kojem se primenjivao Austrijski građanski zakonik, ugovori o doživotnom izdržavanju kojima se imovina primaoca izdržavanja prenosi na davaoca posle smrti primaoca izdržavanja, nisu bili dozvoljeni (preciznije, smatrani su ništavim), jer su kvalifikovani kao ugovori o nasleđivanju, osim ukoliko nisu bili zaključeni između bračnih drugova, što je, posmatrano iz današnje perspektive, bitno ograničenje slobode ugovaranja kada je reč o ovom modalitetu ugovora o doživotnom izdržavanju.

Pomenuti zakon o nasleđivanju prvi put u nas reguliše ugovor o doživotnom izdržavanju, ${ }^{6}$ a budući da ni taj, a ni Zakon o nasleđivanju Republike Srbije iz 1974. godine ${ }^{7}$ (donesen kao rezultat promene nadležnosti za oblast naslednog prava unutar SFRJ, gde je nadležnost prebačena sa saveznog na republički nivo) ne sadrže nikakve specifičnosti u pogledu toga ko može biti davalac izdržavanja, u odnosu na sada važeći Zakon o nasleđivanju Republike

4 „Službeni list FNRJ“, br. 20/1955, koji u Glavi četvrtoj -Naslednopravni ugovori, Odeljku III - Ugovor o doživotnom izdržavanju, čl. 122-127. predviđa i reguliše ovaj ugovor.

5 U situaciji kada postoje porodične zadruge, starija lica ne moraju da brinu za svoju egzistenciju jer u okviru zadruge uvek ima mlađih koji će svojim radom obezbediti sigurnost svim članovima zadruge, pa se potreba za zaključenjem ugovora o doživotnom izdržavanju javlja samo u slučaju postojanja tzv. inokosne porodice. U prilog ovom objašnjenju svakako ide i činjenica da se u gradskim sredinama, u kojima su porodične zadruge dosta ranije odumrle, praksa zaključivanja ovog ugovora ni $\mathrm{u}$ čemu bitnom ne razlikuje od prakse drugih evropskih zemalja.

$6 \quad$ Ni ovaj zakon a ni zakoni koji su mu sledili (republički Zakon o nasleđivanju iz 1974. i Zakon o nasleđivanju iz 1995) ne regulišu oblik ovog ugovora kada se prenos imovine sa primaoca izdržavanja na davaoca izdržavanja vrši neposredno po zaključenju ugovora. To bi svakako trebalo imati u vidu prilikom eventualnog rada na kodifikaciji građanskog prava kod nas.

7 „Službeni glasnik SRS“, br. 52/74, 1/80 i 25/82. 
Srbije, ${ }^{8}$ ovo pitanje obradiću u daljem tekstu pre svega imajući u vidu pozitivno zakonodavstvo Republike Srbije.

\section{KRATAK UPOREDNO PRAVNI OSVRT}

Ugovor o doživotnom izdržavanju u građanskim kodifikacijama. Budući da se javlja u periodu feudalizma i da tada dostiže svoj najveći sjaj, ugovor o doživotnom izdržavanju smatran je institutom feudalnog prava i kao takav nije našao mesta u vodećim građanskim zakonicima XIX veka, pa ni u onim zemljama gde su već odranije postojali propisi o njemu. ${ }^{9}$ Tako, francuski Code civil ne sadrži odredbe o doživotnom izdržavanju iako je ovaj ugovor bio izuzetno rasprostranjen, posebno među seljačkim stanovništvom, gde je zaključivan, opet, najčešće između roditelja i dece kao davalaca izdržavanja. Isti slučaj je i sa Austrijskim građanskim zakonikom koji takođe ne sadrži propise o ovom ugovoru. Nešto drugačija je situacija u nemačkom pravu. Naime, iako ni Nemački građanski zakonik ne sadrži odredbe o doživotnom izdržavanju, nemačke pokrajine, koje su odranije imale dugu tradiciju regulisanja ovog ugovora, prilikom donošenja zakona o izvršenju građanskog zakonika regulišu ovaj ugovor. ${ }^{10}$

Za razliku od njih, Švajcarski građanski zakonik reguliše ugovor o doživotnom izdržavanju i to kao poseban obligacioni ugovor. ${ }^{11}$ Pri tome ovaj zakonik ne poznaje nikakva ograničenja u pogledu subjekata, te se prema tome kao davalac izdržavanja može pojaviti svako ono lice koje inače po opštim pravilima obligacionog, odnosno ugovornog prava može biti stranka u ugovoru, dakle i ona lica koja su po zakonu obavezna da se međusobno izdržavaju.

Rešenja u savremenim pravima. U francuskom pravu. Iako ugovor o doživotnom izdržavanju nije regulisan francuskim građanskim zakonikom, on ipak živi u praksi pod nazivom Contract de bail a nourriture - ugovor o ishrani. Ovim ugovorom primalac izdržavanja ustupa svoju imovinu jednom licu - davaocu izdržavanja, uz istovremeno stvaranje obaveze da to lice ustupiocu obezbedi doživotno izdržavanje (pre svega ima se u vidu obaveza obezbeđenja hrane i stana). Kao i u drugim zemljama, tako je i u Francuskoj ovaj ugovor

8 Zakon o nasleđivanju („Službeni glasnik RS“, br. 46/95) reguliše ugovor o doživotnom izdržavanju u čl. 194-205.

9 Iako je ovaj ugovor u početku bio regulisan običajnim pravilima, prvi propisi o ugovoru o doživotnom izdržavanju javljaju se već u XIV i XV veku, pre svega na prostorima pojedinih nemačkih pokrajina gde je i praksa zaključenja ovog ugovora bila najbogatija, zatim u nekim švajcarskim kantonima, kao i u Austriji.

10 Dr Nevenka Subotić-Konstantinović, ibid., „Tako su još pre stupanja na snagu BGB-a (do 1900. godine), zakone o izvršenju donele Bavarska, Hesen, Libek, a kasnije, posle njegovog stupanja na snagu, Virtemberg, Tiringen, Lipe, Šaumburg-Lipe ....".

11 Čl. 521-529. Švajcarskog građanskog zakonika iz 1911. godine. 
„prvenstveno sklapan između roditelja i dece i vezivao se za prenos nepokretnog imanja." 12

U švajcarskom pravu. Pravni režim ugovora o doživotnom izdržavanju u pozitivnom pravu Švajcarske objašnjen je u delu teksta pod naslovom Ugovor o doživotnom izdržavanju u građanskim kodifikacijama, imajući u vidu da pomenuti zakonik predstavlja pozitivno pravo ove zemlje. Na ovom mestu bih samo dodao da je u švajcarskom pravu ugovor o doživotnom izdržavanju imenovan ugovor pod nazivom Erbverperundung. Takođe, specifičnosti pravnog režima ovog ugovora u slučaju kada se kao davalac izdržavanja javlja lice koje je naslednik primaoca obradiću u daljem tekstu u odgovarajućem delu.

U nemačkom pravu. U nemačkom pravu ugovor o doživotnom izdržavanju (iako neregulisan građanskim zakonikom) javlja se pod imenom Altenteil. Ovim ugovorom vlasnik određenih imovinskih celina obezbeđuje za sebe, ali često i za svog bračnog druga, doživotno izdržavanje, ustupajući te imovinske celine licu koje je obavezno da mu daje izdržavanje. Upisom u zemljišne knjige pravo ustupioca postaje realni teret, pa se u tom slučaju pri regulisanju ovih odnosa shodno primenjuju odredbe o realnim teretima.

U hrvatskom pravu. U hrvatskom pozitivnom pravu ugovor o doživotnom izdržavanju regulisan je Zakonom o nasleđivanju kao imenovan ugovor pod nazivom ugovor o doživotnom uzdržavanju. ${ }^{13}$ Iako ima određenih razlika u odnosu na pravni režim ugovora o doživotnom izdržavanju u našem pravu u pogledu toga ko može biti davalac izdržavanja, što je tema ovog rada, ne postoje neke specifičnosti i problemi koji se razlikuju u odnosu na problematiku našeg prava.

U crnogorskom pravu. Za razliku od našeg i prava Hrvatske, crnogorsko pravo ugovor o doživotnom izdržavanju reguliše u Zakonu o obligacionim odnosima. ${ }^{14}$ Ovim zakonom ostalo se na tragu rešenja iz Zakona o nasleđivanju Crne Gore donetog za vreme postojanja bivše države, kojim je gotovo na isti način kao i u našem zakonu uređen režim ugovora o doživotnom izdržavanju. Čak je predviđen i poseban razlog ništavosti ovog ugovora u slučaju da se kao davalac izdržavanja javlja fizičko ili pravno lice koje se u okviru svog zanimanja, odnosno delatnosti stara o primaocu izdržavanja. ${ }^{15}$ Štaviše, ovaj član je i stilizovan na potpuno isti način kao u našem Zakonu o nasleđivanju.

12 Dr Nevenka Subotić-Konstantinović, op. cit., str. 22.

13 Vidi Zakon o nasleđivanju Republike Hrvatske iz 2003. godine, čl. 116-121.

14 Vidi Zakon o obligacionim odnosima Republike Crne Gore iz 2008. godine, čl. 10751086.

15 Član 1077. Zakona o obligacionim odnosima Republike Crne Gore iz 2008. godine glasi: „Ništav je ugovor u kome je davalac izdržavanja fizičko ili pravno lice koje se u okviru svog zanimanja, odnosno delatnosti stara o primaocu izdržavanja (medicinsko osoblje, bolnice, razne agencije i sl.), ako prethodno za ugovor nije dobijena saglasnost nadležnog organa starateljstva.“ 
Ovde treba napomenuti da, za razliku od našeg i crnogorskog prava, novi hrvatski Zakon o nasleđivanju ne predviđa ovaj poseban razlog ništavosti.

$\mathrm{Na}$ ovom mestu bih još skrenuo pažnju i na postojeće rešenje u Zakonu o nasleđivanju Republike Srpske, po kojem ugovor o doživotnom izdržavanju mogu međusobno zaključiti lica koja su po zakonu obavezna da se međusobno izdržavaju. ${ }^{16} \mathrm{Na}$ značaj ovakvog rešenja, ukazaću nešto kasnije.

Ovom prilikom zadovoljio bih se ovako površnim izlaganjem pravnog režima ugovora o doživotnom izdržavanju u navedenim pravnim sistemima, što smatram opravdanim za potrebe ovog rada. Detaljnija analiza ovih režima, sa analizom pojedinih specifičnosti uporednopravnih rešenja, uslediće u nekom budućem radu koji će za predmet imati nešto širu tematiku iz oblasti pravnog režima ugovora o doživotnom izdržavanju.

\section{DAVAlaC IZDRŽAVANJA PREMA POZITIVNOM PRAVU Republike SRbije}

Izvori prava. Kada govorimo o izvorima prava relevantnim za pitanje ko može biti davalac izdržavanja kod ugovora o doživotnom izdržavanju, polazimo pre svega od matičnog zakona za ovu oblast a to je Zakon o nasleđivanju RS iz 1995. godine koji, kao imenovan, reguliše ugovor o doživotnom izdržavanju. Od značaja za ovu materiju svakako je i Zakon o obligacionim odnosima, kao lex generalis za oblast ugovornog prava, pa samim tim i za ugovor o doživotnom izdržavanju. Na kraju, od značaja su, kao što ćemo u daljem tekstu i videti, i neki drugi propisi, a na prvom mestu Porodični zakon Republike Srbije iz 2005. godine.

Opšte pravilo. Ugovor o doživotnom izdržavanju je u matičnom zakonu definisan na sledeći način: „Ugovorom o doživotnom izdržavanju obavezuje se primalac izdržavanja da se posle njegove smrti na davaoca izdržavanja prenese svojina tačno određenih stvari ili kakva druga prava, a davalac izdržavanja se obavezuje da ga, kao naknadu za to, izdržava i da se brine o njemu do kraja njegovog života i da ga posle smrti sahrani." (član 194. stav 1. ZON RS) Dakle, polazeći od zakonske definicije, davaoca izdržavanja možemo odrediti kao onu ugovornu stranu koja se obavezala da izdržava drugu ugovornu stranu ili treće lice do kraja njihovih života. Iz ovakvog određenja davaoca izdržavanja proizlazi da davalac izdržavanja može biti svako poslovno sposobno lice, fizičko ili pravno. Kad je reč o fizičkim licima, poslovna sposobnost se stiče sa punoletstvom, što je po našem pravu sa navršenih 18 godina života, i traje do smrti, osim ukoliko odlukom nadležnog organa u zakonom određenom postupku fizičko lice ne bude potpuno ili delimično lišeno poslovne sposobnosti. Kada je reč o pravnim licima, situacija je unekoliko drugačija, što ćemo videti u nastavku teksta.

16 Vidi član 139. tačka 3. Zakona o nasleđivanju Republike Srpske. 
Sporna pitanja i ograničenja. Ovakvo određenje davaoca izdržavanja ostavlja otvorenim neka pitanja koja su izazivala ili još izazivaju neslaganja kako u praksi tako i u pravnoj teoriji. Neka od tih pitanja su u ovom momentu možda izgubila na značaju, ali u odsustvu preciznog zakonskog regulisanja ipak ostavljaju prostora za različita tumačenja, što nikako ne može biti beznačajno sa aspekta pravne sigurnosti. Sva ta pitanja se odnose uglavnom na to da li određeno lice i pod kojim uslovima može biti davalac izdržavanja? Ta pitanja su sledeća: 1) da li se ugovor o doživotnom izdržavanju može zaključiti preko punomoćnika; 2) da li zakonski zastupnik poslovno nesposobnog lica može da zaključi ugovor o doživotnom izdržavanju u njegovo ime, kao davaoca izdržavanja; 3 ) da li više lica mogu da se jave kao davaoci izdržavanja; 4) pod kojim uslovima pravno lice može da bude davalac izdržavanja; 5) da li ugovor o doživotnom izdržavanju može da se zaključi između srodnika i lica koja imaju zakonsku obavezu izdržavanja; 6) da li ugovor o doživotnom izdržavanju može biti zaključen između bračnih drugova? U nastavku teksta pokušaću da obradim na adekvatan način svako od ovih pitanja, da ukažem na postojeća stanovišta po tim pitanjima sa osvrtom na to kakvu su evoluciju pojedina od ovih pitanja doživela u sudskoj praksi pre svega naših sudova. Takođe, posebno ću se zadržati na jednom zakonskom ograničenju u pogledu toga ko može biti davalac izdržavanja kod ugovora o doživotnom izdržavanju predviđenom u članu 196. ZON-a.

Da li se ugovor o doživotnom izdržavanju može zaključiti preko punomoćnika? Iako se pitanje postavljeno na ovaj način odnosi po prirodi stvari na oba subjekta ugovora i to podjednako na davaoca i na primaoca izdržavanja, smatram da to ne umanjuje značaj ovog pitanja, u kontekstu toga ko može biti davalac izdržavanja kod ugovora o doživotnom izdržavanju. Zakon o nasleđivanju, ni ovaj sadašnji a ni njegovi prethodnici, ne daje odgovor na ovo pitanje. U pravnoj teoriji i praksi postoje suprotstavljena stanovišta. Po jednom od njih, nije moguće zaključenje ugovora o doživotnom izdržavanju preko punomoćnika i tako zaključen ugovor bio bi ništav. Tako dr Nevenka Subotić-Konstantinović u svojoj doktorskoj tezi ${ }^{17}$ iznosi stav da „...obavezno istovremeno lično prisustvo ugovornika koje pretpostavlja i proveravanje njihovih identiteta i međusobno upoznavanje njihovih porodičnih i imovinskih prilika prilikom zaključenja ugovora, nesumnjivo smanjuje moguće zablude o njihovim ličnostima i osobinama... Davalac izdržavanja, prema tome, ne bi mogao da zaključi ugovor preko punomoćnika."18 Ovakav stav neko vreme zauzimali su i sudovi ondašnje savezne države. ${ }^{19}$ Prema suprotnom gledištu,

17 Dr Nevenka Subotić-Konstantinović, op. cit., str. 46.

18 Sličan stav zastupa i Kosta Mesarović u: Pravni položaj stranaka kod ugovora o doživotnom izdržavanju, Glasnik Advokatske komore APV, br. 12/1963.

19 Pogledati: Rešenje Saveznog vrhovnog suda Rev. br. 475/59 od 17. oktobra 1959. godine, koje glasi: „Pod pojmom ugovornika treba podrazumjevati samo stranke koje za sebe zasnivaju pravni odnos, zbog čega ugovor o doživotnom izdržavanju, 
zaključivanje ugovora o doživotnom izdržavanju je pravno valjano. U tom smislu Ljubomir Vukotić ističe: „Zašto bi se ostavila mogućnost da se preko punomoćnika zaključi brak, da se da izjava o primanju nasleđa i o odricanju od nasleđa (koja je neopoziva) a da se to pravo isključi kod zaključenja ugovora o doživotnom izdržavanju. “ ${ }^{20}$ Nešto drugačiji stav, ali u osnovi sa istom krajnjom konsekvencom - da nije nemoguće zaključiti ugovor o doživotnom izdržavanju preko punomoćnika - zastupaju i prof. dr Oliver Antić i prof. dr Borislav Blagojević, koji kažu da „u načelu ovaj ugovor ne može zaključiti ni punomoćnik lica koje želi da bude davalac izdržavanja, osim ukoliko pri izdavanju punomoćja nisu ispunjeni svi elementi forme koji se traže za ovaj ugovor. “21 Dakle, ovi autori dozvoljavaju mogućnost zaključenja ugovora o doživotnom izdržavanju preko punomoćnika uz ispunjenost elemenata forme koji se zahtevaju za ugovor prilikom izdavanja punomoćja. Sličan stav zastupa i Đemaludin Mutapčić koji kaže „da se ovaj ugovor može zaključiti preko punomoćnika ukoliko je punomoć sastavljena u formi koja se traži za ugovor o doživotnom izdržavanju. “22

Smatram da se stav da se ugovor o doživotnom izdržavanju ne može zaključiti preko punomoćnika ne može sa uspehom braniti jer mi se čini da argumentacija koju koriste zastupnici ovog stanovišta nije dovoljno ubedljiva. Naime, prvo ne stoji argument da se prilikom overe ugovora od strane sudije ugovorne strane upoznaju u pogledu „porodičnih i imovinskih prilika“, jer nam život govori upravo suprotno - da se ugovorne strane veoma dobro poznaju i pre nego što pristupe zaključenju i overi ugovora pred sudom. Drugo, iako zakonski zahtev forme ovog ugovora propisuje da sudija prilikom zaključenja ugovora mora zainteresovane strane upoznati sa posledicama zaključenja ovog ugovora (što smatram ujedno i najsnažnijim argumentom pristalica stanovišta da se ugovor o doživotnom izdržavanju mora zaključiti lično), a što implicira njihovo istovremeno prisustvo prilikom zaključenja ugovora, smatram da bi trebalo dozvoliti zaključenje i preko punomoćnika ali pod strogo propisanim uslovima. Ti bi uslovi bili, pre svega, da punomoćje bude dato u formi koja je potrebna za zaključenje ugovora o doživotnom

zaključen preko punomoćnika, treba smatrati ništavim. Ništav je ugovor o doživotnom izdržavanju zaključen preko punomoćnika ako punomoć nije izdata pod uslovima forme iz člana 122. Zakona o nasleđivanju.“ u: Mr Milenko Ubavić, Ugovor o doživotnom izdržavanju sa sudskom praksom, Beograd 1999, str. 75.

Isto: Presuda Okružnog suda u Beogradu Gž. br. 1488/82, koja glasi: „... Ništav je ugovor o doživotnom izdržavanju koji je zaključen između punomoćnika primaoca izdržavanja i davaoca izdržavanja." Više o ovome: Mr Milenko Ubavić, op. cit., str. 76.

20 Ljubomir Vukotić, Zaključivanje ugovora o prometu nepokretnosti preko punomoćnika, Pravni život, br. 9-10/1993.

21 Dr Borislav Blagojević, Dr Oliver Antić, Nasledno pravo, Beograd 1991, str. 386.

22 Đemaludin Mutapčić, Ugovor o doživotnom izdržavanju u praksi prvih notara u Bosni $i$ Hercegovini, u: Zbornik radova Aktuelnosti građanskog i trgovačkog zakonodavstva i pravne prakse, br. 6, Mostar 2008, str. 609. 
izdržavanju, ${ }^{23}$ da tačno i precizno bude određen saugovornik strane koja daje punomoćje i da budu već u punomoćju određeni bitni elementi ugovora o doživotnom izdržavanju na koji se konkretno punomoćje odnosi. Na taj način bio bi otklonjen nedostatak forme, koji se javlja usled toga što prilikom zaključenja ugovora strana koja daje punomoćje nije prisutna i sudija ne može da je pouči o pravnim posledicama zaključenja ugovora o doživotnom izdržavanju, jer je već prilikom overe punomoćja ta forma zadovoljena, odnosno sudija će prilikom overe punomoćja upozoriti stranu koja izdaje punomoćje na pravne posledice zaključenja ugovora. Ipak, smatram da bi zaključivanje ugovora o doživotnom izdržavanju preko punomoćnika, iako načelno dozvoljeno pod prethodno iznesenim uslovima, trebalo tretirati kao izuzetak u odnosu na pravilo da se ugovor o doživotnom izdržavanja kao ugovor intuitu personae zaključuje, uz istovremeno i lično prisustvo ugovornih strana, samo u slučaju kada zaista postoje naročito opravdane okolnosti koje onemogućuju jednu od ugovornih strana (ili obe) da pristupi zaključenju ovog ugovora pred sudom. Koje će to okolnosti biti, faktičko je pitanje i sud bi ih trebalo ispitivati svaki put prilikom overe punomoćja za zaključenje ugovora.

U prilog ovom stavu ide i praksa naših sudova u poslednje dve decenije (mada ima i suprotnih primera) ${ }^{24}$ koja dozvoljava zaključenje ugovora o doživotnom izdržavanju i preko punomoćnika, bilo da je davalac punomoćja davalac ili primalac izdržavanja, naravno uz zahtev da punomoćje zadovolji uslov forme koja se zahteva za ugovor o doživotnom izdržavanju. Tako „Punomoćje za zaključenje ugovora o doživotnom izdržavanju mora biti u istoj formi u kojoj se zaključuje i sam ugovor o doživotnom izdržavanju. “25

Treba napomenuti da se prethodno obrađeno pitanje više odnosi na sam način zaključenja ugovora (preko punomoćnika), a ne na samu sposobnost nekog lica da zaključi ugovor o doživotnom izdržavanju. Međutim, s obzirom na to da je reč o licu koje uzeto in abstracto ima mogućnost da zaključi ugovor o doživotnom izdržavanju, a da se zbog načina na koji to želi da uradi in concreto ovo pitanje postavlja, i to kao potencijalno ograničenje u pogledu ličnosti davaoca (ali i primaoca, u zavisnosti od toga ko daje punomoćje) izdržavanja, mislim da zavređuje da nađe svoje mesto u ovom radu.

23 Forma ugovora propisana je članom 195. ZON-a iz 1995. godine.

24 Presuda Četvrtog opštinskog suda u Beogradu P. 1714/94 od 16. decembra 1994. godine, Mr Milenko Ubavić, op. cit., str. 76.

25 Vrhovni sud Srbije REV. br. 931/97 od 25. marta 1997. godine, prema navodima: $\mathrm{Mr}$ Milenko Ubavić, ibid., str. 77.

Slično tome: Vrhovni sud Srbije, REV. br. $4632 / 96$ od 3. decembra 1996. godine: „Zakon o nasleđivanju u delu koji se odnosi na ugovor o doživotnom izdržavanju, ne isključuje mogućnost zaključenja ugovora o doživotnom izdržavanju preko punomoćnika. Kako se po pravilu svi pravni poslovi mogu zaključivati preko punomoćnika, onda to važi i za ugovor o doživotnom izdržavanju, uz uslov da punomoćje bude izdato u onoj formi koja važi i za sam ugovor (član 90. ZOO)“ u: Izbor sudske prakse, Beograd, br. 4/2006. 
Da li zakonski zastupnik poslovno nesposobnog lica može da zaključi ugovor o doživotnom izdržavanju u njegovo ime, kao davaoca izdržavanja? Prema opštim pravilima građanskog prava, za zaključenje bilo kog ugovora, pa i ugovora o doživotnom izdržavanju, zahteva se određeni stepen poslovne sposobnosti potreban za zaključenje tog ugovora. Konkretno, za zaključenje ugovora o doživotnom izdržavanju zahteva se postojanje potpune poslovne sposobnosti za davaoca izdržavanja. Lice koje je delimično ili potpuno lišeno poslovne sposobnosti (maloletno lice ili lice nesposobno za rasuđivanje) ne bi moglo biti davalac izdržavanja kod ugovora o doživotnom izdržavanju. ${ }^{26} \mathrm{Ni}$ zakonski zastupnik poslovno nesposobnog lica ne može u njegovo ime zaključiti ugovor o doživotnom izdržavanju, u kojem bi se takvo lice javilo kao davalac izdržavanja. ${ }^{27}$ Ovo zato što je "priroda obaveza koje se ugovorom nameću davaocu izdržavanja, da je to lična obaveza koju je davalac dužan da trajno ispunjava, a da se ne radi o raspolaganjima imovinom, staralac maloletnog ili poslovno nesposobnog lica ne bi mogao da zaključi ugovor o doživotnom izdržavanju za svog štićenika kao davaoca izdržavanja, te se tako i ove kategorije subjekata ne mogu pojaviti u svojstvu davaoca." ${ }^{28}$

Da li više lica mogu da se jave kao davaoci izdržavanja? U pravnoj teoriji, ali što je još važnije u praksi naših sudova, nema spora o tome da se na strani davaoca izdržavanja mogu naći dva ili više lica (isti stav je i po pitanju više lica na strani primaoca izdržavanja). U tom slučaju, takva lica odgovaraju solidarno za obavezu izdržavanja primaocu, jer je predmet njihove obaveze nedeljiv, ${ }^{29}$ naravno ukoliko šta drugo nije ugovoreno u pogledu obaveze svakog od njih ponaosob. Solidarnost na strani davaoca izdržavanja može nastati na dva načina: prvo, kada se više lica istovremeno obavežu kao davaoci izdržavanja već prilikom zaključenja ugovora i drugo, kada naslednici umrlog davaoca izdržavanja nastave ugovorni odnos sa primaocem. Dakle, u ovom drugom slučaju, u početku je postojao samo jedan davalac izdržavanja da bi, nakon njegove smrti, došlo do pojave više lica na strani davaoca izdržavanja. U prvom slučaju, najčešće se kao davaoci izdržavanja javljaju bračni drugovi. Međutim, „ako ugovor zaključi samo jedan od njih, onda u praksi nastaju teškoće oko utvrđivanja kome pripada primaočeva imovina... “ ${ }^{30}$ Mislim da je najbolje rešenje za ovu situaciju postaviti pitanje da li je supružnik davalac izdržavanja davao izdržavanje iz sopstvene ili iz zajedničke imovine? Ukoliko je izdržavanje davao iz sopstvene imovine, onda imovina primaoca izdržavanja

26 Suprotno: Mr Milenko Ubavić, op. cit., str. 19-20.

Isti stav zauzima i Đemaludin Mutapčić, op. cit., str. 613-614.

27 Kada je reč o primaocu izdržavanja, ova mogućnost nije isključena i načelno je dozvoljena uz odobrenje organa starateljstva, u skladu sa Zakonom o braku i porodici.

28 Dr Nevenka Subotić-Konstantinović, op. cit., str. 46.

29 Vidi član 435. Zakona o obligacionim odnosima.

30 Dr Oliver Antić, Zoran Balinovac, Komentar Zakona o nasleđivanju, Beograd 1996, str. 507-508. 
ima da pripadne njemu i obrnuto ${ }^{31} 32$. Deo sudske prakse zastupa suprotan stav - da se tako stečena imovina u svakom slučaju uračunava u zajedničku imovinu bračnih drugova. ${ }^{33}$ Još jedan problem koji se javlja u ovoj situaciji jeste pitanje da li jedan supružnik može da zaključi ugovor o doživotnom izdržavanju kojim se ugovara zajednica života. Takav ugovor bi „zbog samog cilja braka (zajednice života bračnih drugova) bio nepunovažan". ${ }^{34}$ Da bi ovaj ugovor bio punovažan, potrebna je saglasnost ili bolje reći učešće i drugog bračnog druga, i to kao jedne ugovorne strane - davaoca izdržavanja.

U drugoj situaciju postoji solidarnost na strani davaoca izdržavanja - kada naslednici umrlog davaoca preuzmu da daju izdržavanje primaocu izdržavanja. Ovaj slučaj regulisan je Zakonom o nasleđivanju u članu 204. koji pedviđa da obaveza davaoca prelazi na njegovog bračnog druga i potomke koji su pozvani na nasleđe, ako oni na to pristanu. $\mathrm{Na}$ ovaj način „....primalac se obezbeđuje od neprijatne situacije koja za njega može da nastane, ako davalac umre pre njega. "35 Ono što ZON nije regulisao jeste u kojoj formi se vrši preuzimanje obaveze izdržavanja od strane naslednika davaoca. „Taj nedostatak primaoca izdržavanja, često dovodi u jedan vrlo nesiguran položaj, naročito kada ima više takvih sukcesora, pa jedni hoće, a drugi neće nastavljanje ugovora, ili pak, svi hoće, ali niko da u tom pravcu nešto faktički preduzima. “36 Da li u formi aneksa ugovora (što je najčešći slučaj u praksi) ili je možda u formi ostavinskog rešenje iza pokojnog davaoca izdržavanja? Da li preko, odnosno u postupku pred nekim državnim organom (sudom) ili u privatnoj režiji - samoinicijativno (kako se to sada i radi). Smatram da bi ovo pitanje trebalo predvideti u budućoj kodifikaciji građanskog prava u nas, jer bi se na taj način ubrzao i učinio sigurnijim postupak preuzimanja obaveze izdržavanja od strane naslednika davaoca tako što bi sud bio u obavezi da, čim sazna za smrt davaoca izdržavanja (ili u nekom kraćem roku), pozove zainteresovane strane (i potencijalne dava-

31 Tako Marija Draškić, Porodično pravo i pravo deteta, Beograd 2009, str. 364, kaže: „... supružnici su slobodni da zaključuju sve pravne poslove koji se tiču njihovih posebnih imovina... ali i sve one ugovore koji se odnose na režim zajedničke imovine."

32 Odluka Vrhovnog suda Jugoslavije broj GZZ.72/53, „Ako je bračni drug učestvovao svojim radom u izvršavanju ugovora o doživotnom izdržavanju zaključenom između drugog bračnog druga i trećih lica, ima mu se priznati na delu imovine izdržavanog lica pravo kao na zajedničku tekovinu“, prema navodima: Mr Milenko Ubavić, op. cit., str. 114.

33 Vrhovni sud Srbije REV br. 87/79, „Imovina stečena na osnovu ugovora o doživotnom izdržavanju smatra se zajedničkom imovinom bračnih drugova, iako je jedan bračni drug zaključio taj ugovor" prema navodima: Mr Milenko Ubavić, ibid., str. 114.

Videti još: Odluka Okružnog suda u Kragujevcu GŽ. br. 1778/92 od 11. januara 1993. godine.

34 Dr Borislav Blagojević, Dr Oliver Antić, op. cit., str. 386-387.

35 Dr Nevenka Subotić-Konstantinović, op. cit., str. 47.

36 Staniša Paunović, Ugovor o doživotnom izdržavanju, Izbor sudske prakse, Beograd, br. 4/2006, str. 24 . 
oce i primaoca) da daju izjavu da li žele da nastave ugovorni odnos zasnovan ugovorom o doživotnom izdržavanju i, ako to žele, da se preuzimanje izvrži $\mathrm{u}$ formi aneksa ugovora uz ispunjenje zahteva forme koji se inače zahteva za ugovor o doživotnom izdržavanju. Na ovaj način bi u potpunosti bio zadovoljen interes primaoca izdržavanja ali i interes pravne sigurnosti.

Pod kojim uslovima pravno lice može da bude davalac izdržavanja? U načelu, Zakon dozvoljava svakom pravnom licu da bude davalac izdržavanja kod ugovora o doživotnom izdržavanju. Međutim, pravna nauka i praksa izvršili su jedno preciziranje $u$ smislu koji se $i$ inače nameće po logici stvari. Naime, po ovome, pravno lice može da bude davalac izdržavanja samo ukoliko jedna ovakva obaveza (pružanje doživotnog izdržavanja) nije u suprotnosti sa njegovim statutom. „Pravno lice kao davalac izdržavanja može biti neka specijalizovana ustanova ili zavod, kao i svako drugo pravno lice koje je po svojoj delatnosti i strukturi u mogućnosti da pruži doživotno izdržavanje. "37 Tako bi se kao davalac izdržavanja mogla javiti sledeća pravna lica: centri za socijalni rad, domovi za stara lica, domovi zdravlja, ambulante, bolnice, razne agencije specijalizovane za davanje doživotnog izdržavanja, kao i sva druga pravna lica koja su materijalno i tehnički osposobljena za pružanje jedne kompleksne obaveze kao što je davanje izdržavanja. Dakle, pravna lica koja imaju statutom određen delokrug rada koji je nespojiv sa obavezom pružanja izdržavanja ne bi mogla da se jave kao davalac izdržavanja kod ugovora o doživotnom izdržavanju. ${ }^{38}$

Zakon o nasleđivanju iz 1995. godine predviđa jedan poseban slučaj ništavosti ugovora o doživotnom izdržavanju, koji u stvari uvodi jedno bitno ograničenje u pogledu kruga lica koja mogu da zaključe ugovor o doživotnom izdržavanju u svojstvu davaoca izdržavanja, a koje se podjednako odnosi i na pravna i na fizička lica, te ću ga zbog povezanosti sa pravnim licima obraditi na ovom mestu. Član 196. Zakona kaže: „Ništav je ugovor u kome je davalac izdržavanja fizičko ili pravno lice koje se u okviru svog zanimanja, odnosno delatnosti stara o primaocu izdržavanja (medicinsko osoblje, bolnice, različite agencije i slično) ako prethodno za ugovor nije dobijena saglasnost nadležnog organa starateljstva." Ovo ograničenje je uvedeno zbog čestih zloupotreba koje su se dešavale u praksi, posebno u periodu velike ekonomske krize i hiperinflacije početkom devedesetih godina prošlog veka. ${ }^{39}$ Tada su brojna stara lica bez tekućih primanja (i bez srodnika koji su imali mogućnosti da ih izdržavaju), ali sa vrednom nepokretnom imo-

37 Dr Nevenka Subotić-Konstantinović, ibid., str. 45.

38 Isti stav zastupaju: Dr Oliver Antić, Zoran Balinovac, op. cit., str. 507: „Davanje izdržavanja pravnih lica ne sme biti u suprotnosti sa njihovom delatnošću."

39 I inače su medicinsko osoblje i osoblje u ustanovama koje se staraju o starim licima, kao i same te ustanove kao pravna lica, tzv. „rizična grupa“ kada je reč o ovoj vrsti zloupotrebe, jer su u neposrednoj mogućnosti da iskoriste ili bolje reći zloupotrebe situaciju u kojoj se nalaze lica o kojima se staraju.

„Tako je uočeno da, u slučajevima kada u bolnicu ili sličnu ustanovu ...dospe staro i iznemoglo lice, koje nema bližih srodnika, ... medicinsko i drugo osoblje ga brzo 
vinom, bila u određenom smislu prinuđena na zaključenje ugovora o doživotnom izdržavanju, a takve situacije su korišćene za razne mahinacije. ${ }^{40}$ Vođen ovakvom praksom, naš zakonodavac je, po mom mišljenju više nego opravdano, uveo ovu vrstu ograničenja koja se odnosi na ona pravna i fizička lica koja se staraju o primaocu izdržavanja u vidu zanimanja, odnosno delatnosti. Tako, da bi pomenuta lica (pravna ili fizička) zaključila ugovor o doživotnom izdržavanju sa licem o kojem se inače staraju, moraju da dobiju dozvolu nadležnog organa starateljstva, koje dozvolu daje u formi rešenja a protiv kojeg je dozvoljena posebna žalba nadležnom ministarstvu. Sudija pred kojeg su stranke došle radi overe ugovora o doživotnom izdržavanju ne može ga overiti u nedostatku ove dozvole organa starateljstva, u suprotnom takav ugovor bi bio ništav. Tako je u jednom slučaju poništen ugovor o doživotnom izdržavanju koji je zaključila medicinska sestra sa svojim pacijentom. ${ }^{41}$ Ovde treba istaći da se ovo ograničenje odnosi isključivo na konkretno lice (pravno ili fizičko) koje se u konkretnom slučaju stara o primaocu izdržavanja, a ne na pripadnike jedne profesije kao takve (medicinske pre svega) ili na određenu kategoriju pravnih lica (zdravstvenih i medicinskih ustanova), jer bi to bilo diskriminatorski, a samim tim i u neskladu sa Ustavom Republike Srbije iz 2006. godine.

Da li ugovor o doživotnom izdržavanju može da se zaključi između srodnika i lica koja imaju zakonsku obavezu izdržavanja? Ovo pitanje se postavlja pre svega zbog obaveze zakonskog izdržavanja koja može postojati između davaoca i primaoca izdržavanja, te odnosa te obaveze prema obavezi koja nastaje samim ugovorom o doživotnom izdržavanju. U tom slučaju može se postaviti pitanje opravdanosti ugovaranja obaveze doživotnog izdržavanja kada takva obaveza već postoji po samom zakonu. Ovo pitanje se ne postavlja kao sporno kada je reč o zaključenju ugovora između srodnika među kojima ne postoji zakonska obaveza izdržavanja. U tom slučaju činjenica srodstva nije „ni privilegujući ni otežavajući činilac pri zaključenju ugovora." ${ }^{2} \mathrm{U}$ tom slučaju, kao davalac izdržavanja nesmetano se može javiti srodnik primaoca koji nema zakonsku obavezu izdržavanja prema njemu. Ovo mišljenje je uglavnom nesporno kako u pravnoj nauci tako i u praksi. ${ }^{43}$ Isti stav ima i dr Nevenka

'ubedi' o 'nužnosti' zaključenja ugovora o doživotnom izdržavanju i to upravo sa njima. Dr Oliver Antić, Nasledno pravo, Beograd 2010, str. 356.

40 Tako je u Beogradu u jednim dnevnim novinama izlazio oglas agencije „BDB AGENT“ koja nudi doživotno izdržavanje koje podrazumeva „davanje mesečnih iznosa - apanaže, pomoć u kući, periodične nabavke, obezbeđenje lekarske i druge nege, kao i sve ostalo što ugovorne strane ugovorom preciziraju u 'zamenu za vlasništvo stana ili neke druge nepokretnosti'“. Mr Milenko Ubavić, op. cit., str. 42-43.

41 Vidi: Presuda Okružnog suda u Zrenjaninu, Gž.1435/2000 od 28. novembra 2000. godine u: Dr Oliver Antić, op. cit., str. 356.

42 Dr Oliver Antić, Zoran Balinovac, op. cit., str. 507.

43 „Srodnički odnosi između davaoca i primaoca izdržavanja,... nisu od uticaja na zaključivanje ovog ugovora prema našem pravu.", Dr Nevenka Subotić-Konstantinović, op. cit., str. 43. 
Subotić-Konstantinović koja u svojoj doktorskoj disertaciji kaže: „Rodbinski odnos između primaoca i davaoca izdržavanja nema uticaj na mogućnost zaključenja ugovora u doživotnom izdržavanju prema stanovištu koja zauzimaju savremena zakonodavstva. "44 Takođe, u praksi naših sudova nije bila sporna mogućnost zaključenja ugovora o doživotnom izdržavanju u kojima se kao davalac izdržavanja pojavljuje lice koje ima zakonsku obavezu izdržavanja prema primaocu izdržavanja ${ }^{45}$ iako se u ovom slučaju opravdano može postaviti pitanje odnosa takve obaveze prema obavezi koja postoji po Zakonu, kao što je to pitanje postavljeno i kod ugovora o doživotnom izdržavanju koji između sebe zaključuju bračni drugovi, između kojih takođe postoji obaveza zakonskog izdržavanja. Dakle, interesna situacija je ista kao i u slučaju kada se kao davalac izdržavanja pojavljuje neko lice (po pravilu naslednik primaoca) koje ima zakonsku oabvezu izdržavanja prema primaocu (a nije njegov bračni drug), samo se u prvom slučaju (u slučaju bračnih drugova kao strana ugovornica) to pitanje pojavilo kao sporno kako u nauci tako i u praksi, dok u ovom drugom slučaju uglavnom nije bilo neslaganja oko toga da se kao davalac izdržavanja može javiti lice koje ima obavezu izdržavanja prema primaocu na osnovu zakona (a nije njegov bračni drug). Razlog za ovo, čini mi se neopravdano, razlikovanje dve bitno iste situacije, treba potražiti u nekim istorijskim uslovima ali i u moralnim shvatanjima društva. Naime, istorijski posmatrano, ugovor o doživotnom izdržavanju je i nastao tako što je uglavnom zaključivan između roditelja (kao primalaca) i njihove dece ili bliskih srodnika (kao davalaca), iz razloga koje sam prethodno već naveo na odgovarajućem mestu, odnosno između lica između kojih po savremenom pravu postoji zakonska obaveza izdržavanja. Štaviše, „u nekim propisima ...bilo je dozvoljeno zaključivanje ugovora o doživotnom izdržavanju samo među srodnicima". 46 Tako se u neku ruku čini logičnim zašto se to pitanje nije javilo kao sporno kada je reč o ovim licima. Međutim, s druge strane, kada je reč o bračnim drugovima, ovo pitanje se ne samo javilo kao sporno, nego je u praksi naših sudova dovelo do dijametralno suprotnih odluka, a razloge za ovako suprotnu praksu sudova, kao i teorijske argumente koji su je opravdali (ili doveli do nje) izložiću već u sledećem odeljku.

44 Dr Nevenka Subotić-Konstantinović, ibid., str. 39.

45 „Nije nevaljan ugovor o doživotnom izdržavanju zaključen između dijeteta kao davaoca i roditelja kao primaoca izdržavanja." (Vrhovni sud Bosne i Hercegovine GŽ. 1712/67 od 4. februara 1969. godine),

„Ugovor o doživotnom izdržavanju, zaključen između roditelja, kao primalaca izdržavanja i njihove dece, kao davalaca izdržavanja, ne predstavlja ugovor kojim se raspolaže budućim nasledstvom, već obostrano teretan ugovor i on je punovažan ukoliko ispunjava uslove predviđene članom 117. Zakona o nasleđivanju." (Vrhovni sud Srbije REV. br. 1390/82),

„Zakonska obaveza izdržavanja između strana ugovornica kod ugovora o doživotnom izdržavanju nije smetnja za zaključenje takvog ugovora..." (Vrhovni sud Srbije GZZ. br. 221/88), sve prema navodima: Mr Milenko Ubavić, op. cit., str. 61-63.

46 Prema navodima: Dr Nevenka Subotić-Konstantinović, ibid., str. 39. 
Kada je reč o licima između kojih postoji zakonska obaveza izdržavanja, treba napomenuti da ovakav stav (prethodno izložen) može da dovede do značajnih zloupotreba. Naime, problem se javlja kada postoji više lica koja su istovremeno dužna (na osnovu zakona) da izdržavaju primaoca (najčešće je reč o naslednicima), a on zaključi ugovor o doživotnom izdržavanja samo sa jednim od njih. Tada „treba obratiti pažnju da ugovor o doživotnom izdržavanju nije simulovan i da u sebi ne krije kakav drugi pravni posao (recimo ugovor o poklonu). “47 Gde je tu zloupotreba? Pošto je ugovor o doživotnom izdržavanju teretan ugovor, inter vivos, to imovina obuhvaćena ugovorom ne ulazi u zaostavštinu primaoca izdržavanja. Na taj način se ostali naslednici, posredno, isključuju iz nasleđa. ${ }^{48}$ Ovakva vrsta zloupotrebe pravnih dejstava ugovora o doživotnom izdržavanju nije nepoznata kod nas, ${ }^{49}$ te je usled toga u Nacrtu Zakona o nasleđivanju Republike Srbije iz 1995. godine bilo predviđeno da je „Ništav ugovor o doživotnom nasleđivanju u kome se kao davalac izdržavanja javlja lice koje je po zakonu dužno izdržavati primaoca, ako pre zaključenja ugovora nisu saslušani ostali koji imaju zakonsku obavezu izdržavanja." Ova odredba nije našla svoje mesto u konačnoj redakciji Zakona jer se smatralo da je u praksi teško ostvarljiva. Smatram da je na ovaj način neopravdano prevaljen teret ispitivanja postojanja zloupotrebe prava na praksu, jer sudiji sada ostaje da u svakom konkretnom slučaju, prilikom zaključenja ugovora o doživotnom izdržavanju, u situacijama kada postoji više lica koja imaju zakonsku obaveze izdržavanja, ispituje sve relevantne okolnosti koje mogu eventualno ukazivati na postojanje zloupotrebe u konkretnom slučaju, što ne samo da nije jednostavno, već se teško može i očekivati od suda, imajući u vidu da je ipak reč o ugovoru intuitu personae i da se, u konkretnoj situaciji, tiče porodičnih i ličnih odnosa ugovornih strana, što će kao krajnju konsekvencu imati povećanje broja sporova o ništavosti ugovora o doživotnom izdržavanju. Zbog toga pomenuta odredba iz Nacrta ZON-a nije, po meni, bila suvišna, ili ako je već procenjeno da bi u praksi izazvala teškoće, trebalo je onda na neki drugi način regulisati ovu situaciju i time sprečiti samu mogućnost zloupotrebe. Kao jedno od potencijalnih rešenja neka posluži primer iz švajcarskog prava kojim je predviđeno da se takvim situacijama (kada postoji više lica koja imaju zakonsku obavezu izdržavanja prema primaocu) ugovor o doživotnom izdržavanju ima smatrati kao ugovor o nasleđu, čime je nesumnjivo zaštićen

47 Dr Oliver Antić, Zoran Balinovac, op. cit., str. 507.

48 „Ugovor o doživotnom izdržavanju kao teretni pravni posao ne može se pobijati zbog povrede nužnog dijela." Vrhovni sud Hrvatske REV. br. 1833/84 prema navodima: Mr Milenko Ubavić, op. cit., str. 22.

49 „ako ugovornici nisu išli za tim da saugovarač označen kao davalac izdržavanja stvarno daje izdržavanje ugovaraču označenom kao izdržavano lice i da ovaj drugi stvarno prima izdržavanje iako takva potreba kod ovog drugog nije ni postojala, već se ovim ugovorom htelo samo da se zakonski naslednici izdržavanog lica izigraju u svojim pravima..." Vrhovni sud Srbije GŽ. br. 2907/69 prema navodima: Mr Milenko Ubavić, op. cit., str. 45. 
nužni deo naslednika primaoca izdržavanja. ${ }^{50} \mathrm{Na}$ tragu ovog rešenja je praksa naših sudova u slučaju da ugovor o doživotnom izdržavanju ne ispunjava uslove zakonom propisane forme za punovažnost ugovora, kada se primenom pravila Zakona o obligacionim odnosima o konverziji ugovora ${ }^{51}$ ugovor o doživotnom izdržavanju smatra ugovorom o poklonu, čime se takođe štiti nužni deo nužnih naslednika. Međutim, to je samo za situacije kada ugovor o doživotnom izdržavanju ne ispunjava sve zahteve forme (uz, naravno, neophodnu ispunjenost drugih uslova za konverziju), čime nije rešen problem zloupotrebe koji se javlja kada postoji više lica sa zakonskom obavezom izdržavanja a primalac zaključi ugovor o doživotnom izdržavanju samo sa jednim od njih.

Da li ugovor o doživotnom izdržavanju može biti zaključen između bračnih drugova? Kao najspornije od svih do sada postavljenih pitanja, naročito $\mathrm{u}$ pravnoj teoriji, javlja se upravo pitanje da li supružnici mogu međusobno zaključiti ugovor o doživotnom izdržavanju. Ovo pre svega imajući u vidu samu prirodu braka, postojanje zakonske obaveze izdržavanja između bračnih drugova, poseban imovinski režim braka, kao i naročitu mogućnost zloupotrebe ovog ugovora. Tako se u pravnoj teoriji javljaju dva suprotstavljena stanovišta, prvo, koje kaže da je nedopustivo zaključenje ovog ugovora između supružnika i to iz više razloga, i drugo, po kojem je zaključenje ovog ugovora između supružnika dozvoljeno. Zastupnici prvog stanovišta ističu da je ugovor o doživotnom izdržavanju nedopušten jer „Zakon o nasleđivanju ga ne predviđa; supružnici su dužni, po zakonu, da se izdržavaju; remeti se imovinski režim bračnih drugova koji je imperativno regulisan i zato što bi takav ugovor imao karakter ugovora o nasleđivanju. “52 Isti stav zastupa i naš eminentni teoretičar prof. dr Andrija Gams, koji kaže: „ugovor o doživotnom izdržavanju između bračnih drugova je nedozvoljen i ništav jer su bračni drugovi dužni da se izdržavaju i pomažu pod određenim uslovima i okolnostima, a i zato što aleatorni karakter ugovora o doživotnom izdržavanju može stvoriti nezdrave odnose između bračnih drugova“. 53 Brojni su autori koji su zastupali i zastupaju ovakvo stanovište, ${ }^{54}$ što je nesumnjivo u jednom trenutku imalo i snažan uticaj na praksu naših sudova. ${ }^{55}$

50 Vidi član 521. stav 2. švajcarskog Zakona o obligacijama.

51 Vidi član 106. Zakona o obligacionim odnosima.

52 Boris Vizner, Građansko pravo u teoriji i praksi II knjiga, Osijek 1967, str. 125.

53 Dr Andrija Gams, Bračno i porodično imovinsko pravo, Beograd 1966, str. 80.

54 Tako, dr Nevenka Subotić-Konstantinović ističe: „, da je zaključenje ugovora o doživotnom izdržavanju između bračnih drugova nedopušteno zbog postojanja zakonske obaveze izdržavanja“, u: Ugovor o doživotnom izdržavanju - doktorska disertacija, Beograd 1968, str. 42-43.

Isto mišljenje ima i dr Marko Mladenović, opširnije videti u: Dr Marko Mladenović, Dr Slobodan Panov, Porodično pravo, Beograd 2003, str. 204.

55 „Ugovor o doživotnom izdržavanju zaključen između bračnih drugova protivan je suštini braka i kao takav nedopušten." Odluka Vrhovnog suda Srbije Gž. 92/64, navedeno prema: Dr Rajko Sudžum, Imovinski odnosi bračnih drugova, Beograd 1982, str. 307. 
Suprotno stanovište, koje se javlja nešto kasnije, kaže da ne postoje nikakve smetnje za zaključenje ugovora o doživotnom izdržavanju između bračnih drugova, jer ugovor o doživotnom izdržavanju „nije u koliziji sa zakonskom obavezom izdržavanja “, 56 niti je protivan zakonu a nije ni suprotan prirodi braka. Te da bračni drugovi mogu zaključivati ugovor o doživotnom izdržavanju, isto kao i sve druge ugovore koji nisu protivni prinudnim propisima. (To mišljenje zastupaju V. Bakić, R. Sudžum, B. Blagojević, O. Antić i drugi autori.)

Analizom stavova i argumenata jedne i druge strane zaključio sam da su tri pitanja ključna za pitanje dozvoljenosti ili nedozvoljenosti zaključenja ovog ugovora između bračnih drugova. Prvo je pitanje kolizije obaveze izdržavanja nastale ugovorom o doživotnom izdržavanju i zakonske obaveze izdržavanja između bračnih partnera. Smatram da između ove dve obaveze ne postoji kolizija iz razloga što da bi jedan od supružnika stekao pravo na izdržavanje od drugog supružnika, po osnovu zakona, on mora biti bez sredstava za život, ${ }^{57}$ što u slučaju ugovaranja doživotnog izdržavanja nije slučaj jer on upravo poseduje imovinu (u suprotnom ne bi moglo biti ni ugovora o doživotnom izdržavanju), te prema tome „ne postoji zakonska obaveza drugog bračnog druga da ga izdržava“. ${ }^{58}$ Pored toga, obaveza izdržavanja koja se ugovara sadržinski može biti umnogome različita i prevazilaziti obavezu izdržavanja koja postoji na osnovu zakona. Takođe, trajanje ove dve obaveze izdržavanja je različito, jer zakonska obaveza izdržavanja postoji samo dotle dok postoje razlozi zbog kojih je i nastala. Dakle, očigledno je da između ove dve obaveze izdržavanja nema kolizije, jer se one razlikuju kako u uslovima nastanka, tako i u sadržini ali i u trajanju. Isto stanovište zastupa i prof. dr Radoje Korać koji ističe: „Treba prihvatiti mišljenje prema kome je dozvoljeno zaključenje ovog ugovora između bračnih drugova, to što se kao davalac i primalac izdržavanja javljaju bračni drugovi ne dira u zakonom predviđenu obavezu izdržavanja između njih. Ugovorna obaveza postoji pored zakonske jer se ugovorom raspolaže posebnom imovinom u većem obimu nego kad je u pitanju izdržavanje na osnovu zakona. " ${ }^{59}$ Sličnog mišljenja je i prof. dr Oliver Antić: „Ugovorom o doživotnom izdržavanju niti se derogiraju, niti se izigravaju zakonske odredbe o međusobnom izdržavanju bračnih drugova, naprotiv.“60 Suprotno mišljenje zastupa dr Marko Mladenović: „Od dva osnova jači je zakonski, a on je obavezan i prinudan."61 Takođe, valja napomenuti da u teoriji nikada nije bilo sporno da ugovor o doživotnom izdržavanju mogu da zaključe roditelji sa svojom decom kao davaocima izdržavanja, iako između nih takođe postoje obaveze zakonskog izdržavanja, te bi, u tom

56 Dr Marija Drakšić, Porodično pravo i pravo deteta, Beograd 2009, str. 366.

57 Vidi član 151. Porodičnog zakona Republike Srbije.

58 Dr Marija Drakšić, op. cit., str. 366.

59 Dr Marina Janjić-Komar, Radoje Korać, Zoran Ponjavić, Porodično pravo, Beograd 1996, str. 374.

60 Dr Oliver Antić, Dr Borislav Blagojević, op. cit., str. 387.

61 Dr Marko Mladenović, Dr Slobodan Panov, op. cit., str. 204. 
smislu posmatrano, bilo nepravično uskratiti bračnim drugovima mogućnost zaključenja ovog ugovora.

Drugo je pitanje da li je protivno zakonu zaključenje ugovora o doživotnom izdržavanju između bračnih drugova. Kada je reč o ovom pitanju, treba prvo poći od opšteg pravila po kojem bračni drugovi mogu među sobom sklapati razne imenovane i neimenovane imovinske ugovore, pod uslovom da oni nisu protivni zakonu. Kako ugovor o doživotnom izdržavanju uzeto in abstracto zasigurno nije protivan zakonu, morao bi in concreto (dakle, $\mathrm{u}$ slučaju zaključenja između bračnih drugova) biti zabranjen. Međutim, nijednim zakonskim propisom, ni važećim a ni nekim ranijim, kod nas nikada nije bilo određeno da bračni drugovi ne mogu među sobom sklapati ugovore o doživotnom izdržavanju. „Prema tome, može se pouzdano zaključiti da nije protivan zakonu ugovor o doživotnom izdržavanju zaključen među bračnim drugovima ${ }^{62}$ Činjenica da nije izričito propisan ZON-om nije dovoljna da se smatra zabranjenim (suprotno mišljenje Kosta Mesarović, videti u: Zaključenje ugovora o doživotnom izdržavanju između bračnih drugova, Glasnik AK APV br. 4/64), jer ponavljam - da bi se smatrao zabranjenim, morao bi kao takav biti izričito predviđen zakonom, a to nije slučaj. Ne samo to, već treba reći i da je za vreme postojanja SFRJ, Zakonom o nasleđivanju SR BiH, članom 120. stav 5, bilo izričito predviđeno da bračni drugovi mogu zaključivati ugovor o doživotnom izdržavanju.

Na kraju, treće pitanje je pitanje da li je ovaj ugovor protivan prirodi braka. Budući da je ugovor o doživotnom izdržavanju ugovor intuitu personae, odnosno da je reč o pravnom poslu kod kojeg se ima u vidu naročito poverenje između strana ugovornica, nema razloga smatrati ga protivnim prirodi braka jer upravo u braku postoji takvo naročito poverenje između bračnih drugova. Stoga bi bilo nelogično jednom od bračnih drugova zabraniti sklapanje pravnog posla intuitu personae (kakav je ugovor o doživotnom izdržavanju) sa osobom u koju, po pravilu, ima najviše poverenja. Zbog toga smatram da se ne može sa uspehom braniti stav pojedinih autora da ugovor o doživotnom izdržavanju „može stvoriti nezdrave odnose između bračnih drugova“, 63 ili da „postojanje ovog ugovora znači pravnu i moralnu degradaciju braka i krije u sebi pobude i motive koji su protivni moralnim osnovama braka". 64

Dakle, imajući u vidu da ugovor o doživotnom izdržavanju zaključen između bračnih drugova nije protivan zakonu, da nije u koliziji sa zakonskom obavezom izdržavanja, kao i da nije suprotan prirodi braka, ne bi se smeo smatrati nedozvoljenim u našem pravu. Ovakav stav, posle kraćeg kolebanja izazvanog zakonskim neregulisanjem i teorijskim šarenilom, zauzela je i naša sudska praksa. ${ }^{65}$

62 Dr Oliver Antić, op. cit., str. 354.

63 Dr Andrija Gams, op. cit., str. 80.

64 Dr Marko Mladenović, Dr Slobodan Panov, op. cit., str. 204.

65 „Ni odredbama OZB, ni odredbama republičkih zakona o imovinskim odnosima bračnih drugova, ni odredbama Zakona o nasleđivanju, a ni odredbama drugih zakona i pravnih pravila sadržanih u ranijim zakonima koji bi se, pozivom na član 4 . 


\section{Društveni znaČaj ugovora o DOŽIVOTNOM IZDRŽAVANJU}

Svoju viševekovnu tradiciju ugovor o doživotnom izdržavanju svakako duguje svojim pravnim dejstvima. Pravna dejstva ovog ugovora pokazala su se, kako nekada tako i sada, kao odgovarajuća za zadovoljenje određenih opravdanih interesa ugovornih strana. Naravno, ti interesi nisu isti u savremenom i modernom društvu kao što su bili nekada, pre jednog, dva ili više vekova. Oni su umnogome različiti, ali upravo u tome se vidi sposobnost ovog ugovora za zadovoljenje najrazličitijih interesa u zavisnosti od potreba vremena. Interesi o kojima pričam promenljivi su i zavise pre svega od društveno-ekonomskih uslova života. Koji su to interesi bili nekada, izložio sam nešto ranije u ovom radu (videti Glavu II, str. 4), a na ovom mestu pokušaću da objasnim savremene društvene uslove kojima ugovor o doživotnom izdržavanju duguje svoju „popularnost“ i egzistenciju.

Zaključenjem ovog ugovora, ugovorne strane (davalac i primalac izdržavanja) pred sobom imaju određene ciljeve ili, preciznije rečeno, interese koje žele izvršenjem ovog ugovora da zadovolje. Za razliku od većine drugih obligacionih ugovora, kod ugovora o doživotnom izdržavanju zadovoljenje ovih interesa, odnosno potreba nije trenutno već je odloženo za određeno vreme. To vreme može biti nekada i veoma dugo, po nekoliko godina ili desetina godina. U tome se ogleda aleatornost ovog ugovora, jer ugovorne strane (pre svega davalac izdržavanja) u trenutku zaključenja ugovora još ne zna kolika će njegova obaveza biti. ${ }^{66}$ Međutim, i pored rizika koji nosi potencijalna mo-

Zakona o nevažnosti pravnih propisa donetih pre 6. aprila 1941. godine i za vreme neprijateljske okupacije, mogli primeniti na konkretni slučaj, nije određeno da bračni drugovi ne mogu među sobom sklapati ugovore o doživotnom izdržavanju... Pravo i dužnost bračnih drugova da se uzajamno pomažu (član 4. OZB) i pravo bračnog druga na izdržavanje (član 11. OZB) pod uslovima koje zakon određuje, kao lična prava i dužnosti uslovljena su mogućnostima bračnog druga da pomaže, odnosno izdržava drugog bračnog druga, i to u prvom redu materijalnim mogućnostima i mogućnostima druge vrste pomaganja, kao što je pomoć i nega u bolesti, supružanska pažnja u svakidašnjem životu, pomoć u nezi i odgoju dece, pomoć u savetima i sl. Takva prava i dužnosti bračnih drugova ne isključuju mogućnost da supruzi zaključe i ugovor o doživotnom izdržavanju kad je to u njihovom interesu i kad je to izraz njihove prave volje jer takva ugovorna obaveza po sili ugovora prevazilazi meru obaveze međusobnog pomaganja bračnih drugova." Vidi presudu Vrhovnog suda Jugoslavije Gž. br. 3/68 od 8. marta 1968. godine, Zbirka sudskih odluka, Beograd 1968, knjiga 13, sveska 1, odluka br. 23, prema navodima: Dr Marija Drakšić, op. cit., str. 367.

Isto: „Zaključivanje ugovora o doživotnom izdržavanju između bračnih drugova nije zakonom zabranjeno i ne protivi se načelu socijalističkog morala i kada su obaveze davaoca izdržavanja identične s njegovim zakonskim obavezama bračnog izdržavanja." Vidi presudu Vrhovnog suda Vojvodine REV. br. 3/88, prema navodima: $\mathrm{Mr}$ Milenko Ubavić, op. cit., str. 62.

66 Dr Obren Stanković, Pravni poslovi, u: Dr Obren Stanković, Dr Vladimir Vodinelić, Uvod u građansko pravo, Beograd 1996, str. 167: „Aleatorni ugovori (ugovori na sre- 
gućnost višegodišnjeg (ili čak višedecenijskog) trajanja ovog ugovora, to nije odvraćajući faktor koji presudno utiče na motive davaoca izdržavanja. Davalac izdržavanja u ovom ugovoru vidi mogućnost da dođe do svojine na određenim stvarima primaoca izdržavanja, po pravilu nepokretnostima. Vrednost te imovine nije zanemarljiva i zaista su retki slučajevi u kojima ukupna vrednost činidbe davaoca izdržavanja nadilazi vrednost te imovine. To je osnovni motiv davaoca izdržavanja. Dakle, imovinski aspekt ovog ugovora u savremenim društvenim uslovima preteže, bar kada je reč o davaocu izdržavanja, nad njegovim ličnim aspektom, iako je i danas ugovor o doživotnom izdržavanju zadržao karakter ugovora intuitu personae. Naravno, ne treba zanemariti moralnu i humanu komponentu na strani davaoca izdržavanja, posebno u slučajevima kada on svoju obavezu pružanja izdržavanja izvršava savesno i požrtvovano, trudeći se da na različite načine pomogne primaocu izdržavanja u starosti i bolesti, olakšavajući mu tako življenje u tom poslednjem periodu života.

Davalac izdržavanja je obezbeđen zaključenjem ovog ugovora u tom smislu da imovina koja je predmet ovog ugovora ne ulazi u zaostavštinu primaoca izdržavanja, pa čak ni njegovi nužni naslednici ne mogu da se namire iz nje. Ovakvo svoje dejstvo ovaj ugovor duguje činjenici da je reč o dvostrano obaveznom i teretnom ugovoru. ${ }^{67}$ Upravo ovo dejstvo otvara mogućnosti za razne zloupotrebe uvog ugovora, pre svega za posredno isključenje iz nasledstva pojedinih srodnika, što je osobito u ruralnim predelima česta pojava.

Motivi primaoca izdržavanja su, sa druge strane, sasvim različiti od motiva davaoca izdržavanja. Naime, u savremenom društvu, u društvu kada su velike porodice sa više generacija i u kojima postoji poštovanje i nega najstarijih članova samo zanemarljivi izuzeci i relikti prošlosti, postavlja se ozbiljno društveno pitanje staranja o licima koja više nisu sposobna za rad. Idealna bi bila situacija u kojoj je država, odnosno društvo to koje ima sve preduslove, na prvom mestu materijalne, da kroz svoje institucije može u potpunosti da obezbedi adekvatnu negu za stara, bolesna i lica koja nisu u mogućnosti da se u odmakloj životnoj dobi na adekvatan način brinu o sebi i imovini koju poseduju. Međutim, kao što je dobro poznato, takva situacija dobrim delom, posebno posmatrajući iz perspektive u kojoj se mi sada nalazimo (društvo u tranziciji, sa propalim penzijskim fondovima, niskom stopom rasta, u kojem i za rad sposobna lica ,jedva sastavljaju kraj sa krajem“), deluje utopijski. U takvim društvenim, ekonomskim i porodičnim uslovima stara, iznemogla i za rad nesposobna lica svoju egzistenciju u starosti obezbeđuju zaključivanjem ugovora o doživotnom izdržavanju.

ću) odlikuju se time što se u vreme njihovog zaključenja ne zna ko će biti poverilac a ko dužnik (kao kod ugovora o opkladi) ili se ne zna kakav će biti krajnji odnos uzajamnih davanja stranaka (to će se znati kasnije), kakvi su npr. ugovor o doživotnom izdržavanju (gde se ne zna koliko će dugo živeti primalac izdržavanja i koliko će trajati obaveza izdržavanja).“

67 O pravnoj prirodi ugovora o doživotnom izdržavanju više u: Dr Slobodan Svorcan, Raskid ugovora o doživotnom izdržavanju, Beograd 1987, Glava II. 